\title{
The application of vegetable, fruit and garden waste (VFG) compost in addition to cattle slurry in a silage maize monoculture: Effects on soil fauna and yield
}

\author{
Ben L.M.M. Leroy ${ }^{\mathrm{a}, *}$, Lydia Bommele ${ }^{\mathrm{b}}$, Dirk Reheul ${ }^{\mathrm{b}}$, \\ Maurice Moens ${ }^{\text {c,d }}$, Stefaan De Neve ${ }^{\text {a }}$ \\ ${ }^{\text {a }}$ Ghent University, Department of Soil Management and Soil Care, Faculty of Bioscience Engineering, \\ Coupure Links 653, 9000 Gent, Belgium \\ ${ }^{\mathrm{b}}$ Ghent University, Department of Plant Production, Coupure Links 653, 9000 Gent, Belgium \\ ${ }^{\mathrm{c}}$ Institute for Agricultural and Fisheries Research, Burg. Van Gansberghelaan 96, 9820 Merelbeke \\ ${ }^{\mathrm{d}}$ Ghent University, Department of Crop Protection, Coupure Links 653, 9000 Gent, Belgium
}

Received 1 March 2006; accepted 23 October 2006

Available online 27 November 2006

\begin{abstract}
In Flanders, vegetable, fruit and garden (VFG) wastes are collected selectively and composted. We studied the effects of the combined application of three different doses of VFG compost and cattle slurry during 7 years on maize dry matter yields and three soil faunal groups: nematodes, micro-arthropods (springtails and mites) and earthworms. Combined application of VFG compost and slurry resulted in the highest yields. Initially, there was a clear yield depression on plots amended with compost in contrast to an upward trend in the last application years, proving a significant residual $\mathrm{N}$ effect from cumulative compost applications. The plant parasitic nematodes Pratylenchus sp. and the Tylenchidae were less abundant on plots receiving organic amendments, while the population of the bacteriophagous Rhabditidae was higher on these plots. Adding organic amendments resulted in increased numbers of micro-arthropods, springtails as well as mites. Earthworms were significantly more abundant when organic amendments were applied. The VFG compost had a larger overall positive effect on the three soil faunal groups than cattle slurry.
\end{abstract}

(c) 2006 Elsevier Masson SAS. All rights reserved.

Keywords: VFG compost; Cattle slurry; Nematodes; Springtails; Mites; Earthworms; Yield

\section{Introduction}

The selective collection of the organic fraction of household wastes, collectively referred to as vegetable, fruit and garden wastes (VFG), opens perspectives

\footnotetext{
* Corresponding author. Tel.: +329264 6057; fax: +32 9264 6247.

E-mail address: ben.leroy@ugent.be (B.L.M.M. Leroy).
}

for its reuse in plant production. In the region of Flanders (North of Belgium), VFG wastes have been collected selectively and composted from 1992 on, to produce VFG compost [2]. Over time the amount of waste collected and the compost produced from it has grown steadily. In 2005, about 370000 ton VFG waste was collected from which 136000 ton VFG compost was produced (compared to about 34600 ton VFG waste and 12000 VFG compost in 
1992). Currently the main share of this compost is used for non-professional applications. However, agriculture and horticulture can be considered potentially important purchasers of VFG compost in the future. The main reason why this compost is not widely used there yet, is a lack of knowledge of its agronomic value.

Compost was shown to: (i) protect the soil against erosion [3,19]; (ii) to have beneficial effects on soil physical properties such as total porosity, saturated hydraulic conductivity, available water content [9] and aggregate stability [15]; (iii) to decrease soil acidity [36] and soil bulk density [9]; and (iv) to increase soil organic matter content [9]. Additionally, composts have the potential to protect crops against pathogens $[11,16,25,35]$, which has been attributed to different mechanisms, such as increased parasitism and antibiosis and induced resistance [24]. There is evidence that immature compost can be used for weed control, due to the presence of phytotoxins like acetic and propionic acid [30].

The use of compost has a significant impact on the soil fauna and flora. Pfotzer and Schüler [32] and Forge et al. [21] proved that the application of compost enhanced the biological activity of the soil (higher microbial activity and higher numbers of protozoa and bacterivorous nematodes), resulting in enhanced turnover of organic matter and release of plant available nutrients. Soil biota can be considered important soil quality indicators. In translocating and transforming litter and soil organic matter and in changing the supply of nutrients to plant roots, they fulfil crucial roles in the control of water, nutrients and soil structure [7]. Compost application can strengthen the role of the living soil. This point is often overlooked, because in conventional agriculture the soil biota are effectively bypassed by soil tillage, mineral fertilizers and pesticides. However, if modern agriculture has to rely more on internal resources (e.g. the recycling of organic matter), restoring and sustaining the major functions of the soil biota is pertinent [7].

To date, very few studies exist on the effects of VFG compost application to soil, and to our knowledge no studies examined the combined effect of VFG compost and cattle slurry on crop yield and soil fauna. The aim of this research was to investigate the effects of a combined application of VFG compost and cattle slurry over a 7-year period on maize dry matter (DM) yield and on three soil faunal groups: nematodes, microarthropods (springtails and mites) and earthworms. These groups were chosen as major constituents of the soil food web.

\section{Materials and methods}

\subsection{Experimental design}

The experimental field site, located in Melle (experimental site of Ghent University, Belgium, $50^{\circ} 59^{\prime} \mathrm{N}$, $03^{\circ} 49^{\prime} \mathrm{E}, 11 \mathrm{~m}$ above sea level), was monocropped with maize since 1982. The soil of the experimental site is a sandy loam soil with the following granulometric composition: $10.4 \% 0-2 \mu \mathrm{m}, 42.0 \% 2-50 \mu \mathrm{m}$ and $47.6 \%>50 \mu \mathrm{m}$. From 1997 the field is used for a long term experiment with different types of organic and inorganic fertilizers. A block design with three replicates is used to assess the impact of fertilizer type on maize yield. On 54 experimental units (plot size $9 \mathrm{~m} \times 9 \mathrm{~m}$ ) the following three fertilization treatments and their combinations were applied (Fig. 1):

C: spring application of vegetable, fruit and garden waste (VFG) compost at a rate of $0,22.5$ or 45 ton compost ha ${ }^{-1}$ (C0, $\mathrm{C} 1$ and $\mathrm{C} 2$ respectively) $\mathrm{S}$ : spring application of a variable amount of dairy cattle slurry $(\mathrm{S}+)$ or no slurry application $(\mathrm{S}-$ ) $\mathrm{N}$ : mineral nitrogen fertilization (ammonium nitrate $27 \%)$ of 0,100 and $200 \mathrm{~kg} \mathrm{~N} \mathrm{ha}^{-1}$ year $^{-1}(0 \mathrm{~N}$, $100 \mathrm{~N}$ and $200 \mathrm{~N}$ respectively), applied just before sowing.

Fertilizer and organic matter amendments were applied every year, except the 45 ton $\mathrm{ha}^{-1}$ VGF compost, which was applied every other year. The precise amounts and application dates of compost and manure are shown in Table 1. Table 2 gives the average composition (1997-2003) of the applied cattle slurry and VFG compost. On the plots receiving no slurry, an additional amount of $300 \mathrm{~kg} \mathrm{ha}^{-1} \mathrm{~K}_{2} \mathrm{O}$ and $75 \mathrm{~kg} \mathrm{ha}^{-1}$ $\mathrm{P}_{2} \mathrm{O}_{5}$ was applied yearly. Every year the mineral fertilizer was applied the day following the compost application.

\subsection{Sampling and analysis of soil fauna}

Here we report data collected on plots with no mineral $\mathrm{N}$ fertilization $(0 \mathrm{~N})$. In order to investigate the soil fauna, soil samples were taken in autumn 2003 and in spring 2004.

The sampling for nematodes was done on September 11, 2003 and March 30, 2004. For each plot 40 cores were taken up to a depth of $20 \mathrm{~cm}$, using an auger with a diameter of $1.8 \mathrm{~cm}$, in the centre of the plot and close to the plant rows. All 40 samples were bulked and thoroughly mixed; $200 \mathrm{ml}$ of this bulk sample was 


\begin{tabular}{|c|c|c|c|c|c|c|c|c|c|}
\hline Block & $\begin{array}{c}\mathrm{C} 0 \\
200 \mathrm{~N}\end{array}$ & $\begin{array}{l}\text { C1 } \\
\text { ON }\end{array}$ & $\begin{array}{c}\mathrm{CO} \\
100 \mathrm{~N}\end{array}$ & $\begin{array}{c}\mathrm{C} 2 \\
200 \mathrm{~N}\end{array}$ & $\begin{array}{c}\text { C1 } \\
100 N\end{array}$ & $\begin{array}{c}\mathrm{C1} \\
200 \mathrm{~N}\end{array}$ & $\begin{array}{c}\mathrm{C} 2 \\
100 \mathrm{~N}\end{array}$ & $\begin{array}{l}\text { CO } \\
\text { ON }\end{array}$ & $\begin{array}{l}\text { C2 } \\
\text { ON }\end{array}$ \\
\hline 1 & $\begin{array}{c}\mathrm{C} 2 \\
200 \mathrm{~N}\end{array}$ & $\begin{array}{c}\mathrm{CO} \\
100 \mathrm{~N}\end{array}$ & $\begin{array}{c}\mathrm{CO} \\
200 \mathrm{~N}\end{array}$ & $\begin{array}{l}\text { C2 } \\
\text { ON }\end{array}$ & $\begin{array}{c}\mathrm{C} 2 \\
100 \mathrm{~N}\end{array}$ & $\begin{array}{l}\text { C1 } \\
\text { ON }\end{array}$ & $\begin{array}{c}\mathrm{C} 1 \\
100 \mathrm{~N}\end{array}$ & $\begin{array}{l}\text { CO } \\
\text { ON }\end{array}$ & $\begin{array}{c}\mathrm{C} 1 \\
200 \mathrm{~N}\end{array}$ \\
\hline Block & $\begin{array}{c}\mathrm{CO} \\
100 \mathrm{~N}\end{array}$ & $\begin{array}{c}\mathrm{C} 2 \\
200 \mathrm{~N}\end{array}$ & $\begin{array}{l}\text { C1 } \\
\text { ON }\end{array}$ & $\begin{array}{l}\text { CO } \\
\text { ON }\end{array}$ & $\begin{array}{l}\text { C2 } \\
\text { ON }\end{array}$ & $\begin{array}{c}\mathrm{CO} \\
200 \mathrm{~N}\end{array}$ & $\begin{array}{c}\mathrm{C} 1 \\
200 \mathrm{~N}\end{array}$ & $\begin{array}{c}\mathrm{C} 2 \\
100 \mathrm{~N}\end{array}$ & $\begin{array}{c}\mathrm{C} 1 \\
100 \mathrm{~N}\end{array}$ \\
\hline 2 & $\begin{array}{c}\mathrm{C} 2 \\
200 \mathrm{~N}\end{array}$ & $\begin{array}{l}\text { C2 } \\
\text { ON }\end{array}$ & $\begin{array}{c}\mathrm{CO} \\
200 \mathrm{~N}\end{array}$ & $\begin{array}{c}\mathrm{CO} \\
100 \mathrm{~N}\end{array}$ & $\begin{array}{l}\text { C1 } \\
\text { ON }\end{array}$ & $\begin{array}{l}\text { CO } \\
\text { ON }\end{array}$ & $\begin{array}{c}\mathrm{C} 2 \\
100 \mathrm{~N}\end{array}$ & $\begin{array}{c}\mathrm{C} 1 \\
200 \mathrm{~N}\end{array}$ & $\begin{array}{c}\text { C1 } \\
100 N\end{array}$ \\
\hline Block & $\begin{array}{c}\mathrm{C} 2 \\
200 \mathrm{~N}\end{array}$ & $\begin{array}{l}\text { C2 } \\
\text { ON }\end{array}$ & $\begin{array}{c}\mathrm{CO} \\
200 \mathrm{~N}\end{array}$ & $\begin{array}{c}\mathrm{CO} \\
100 \mathrm{~N}\end{array}$ & $\begin{array}{l}\text { CO } \\
\text { ON }\end{array}$ & $\begin{array}{c}\mathrm{C} 1 \\
200 \mathrm{~N}\end{array}$ & $\begin{array}{c}\mathrm{C} 2 \\
100 \mathrm{~N}\end{array}$ & $\begin{array}{l}\text { C1 } \\
\text { ON }\end{array}$ & $\begin{array}{c}\mathrm{C} 1 \\
100 \mathrm{~N}\end{array}$ \\
\hline 3 & $\begin{array}{c}\mathrm{CO} \\
200 \mathrm{~N}\end{array}$ & $\begin{array}{c}\text { C2 } \\
100 N\end{array}$ & $\begin{array}{c}\mathrm{CO} \\
100 \mathrm{~N}\end{array}$ & $\begin{array}{l}\text { C1 } \\
\text { ON }\end{array}$ & $\begin{array}{l}\text { CO } \\
\text { ON }\end{array}$ & $\begin{array}{c}\text { C1 } \\
100 \mathrm{~N}\end{array}$ & $\begin{array}{l}\text { C2 } \\
\text { ON }\end{array}$ & $\begin{array}{c}\text { C1 } \\
200 N\end{array}$ & $\begin{array}{c}\mathrm{C} 2 \\
200 \mathrm{~N}\end{array}$ \\
\hline & $\begin{array}{c}C \\
O N\end{array}$ & \multicolumn{2}{|c|}{$\begin{array}{c}=\text { sampled } \\
\text { plots }\end{array}$} & & \multicolumn{2}{|c|}{$\begin{aligned}= & \text { slurry } \\
& (\mathrm{S}+)\end{aligned}$} & & \multicolumn{2}{|c|}{$\begin{array}{c}=\text { no slurry } \\
(\mathrm{S}-)\end{array}$} \\
\hline
\end{tabular}

Fig. 1. Experimental design of the field trial: $\mathrm{S}-=$ no slurry, $\mathrm{S}+=$ slurry, $\mathrm{C} 0=$ no compost, $\mathrm{C} 1=22.5$ ton ha ${ }^{-1}$ compost yearly, $\mathrm{C} 2=45$ ton ha ${ }^{-1}$ compost every other year, $0 \mathrm{~N}=0 \mathrm{~kg} \mathrm{~N}$ ha $^{-1}$ yearly, $100 \mathrm{~N}=100 \mathrm{~kg} \mathrm{~N} \mathrm{ha}^{-1}$ yearly, $200 \mathrm{~N}=200 \mathrm{~kg} \mathrm{~N}^{-1}$ yearly.

taken for further analysis. Extraction of nematodes was conducted with a zonal centrifuge, following Hendrickx [23]. Nematodes were identified on family or species level using a stereo dissecting microscope at a magnification of $1000 \times$.

For springtails and mites samples were taken on November 14, 2003 and on March 19, 2004. A single core was removed from the centre of each plot up to a depth of $20 \mathrm{~cm}$, using an auger with a diameter of $4 \mathrm{~cm}$ [12]. A dry extraction with Tullgren funnels was used to remove the micro-arthropods from the samples [13]. The springtails and some of the most abundant mites were identified at family level using a stereo dissecting microscope at a magnification of $400 \times$.
Earthworms were sampled on October 20, 2003 and on March 16, 2004, because in temperate regions earthworms are most active during spring and fall when temperatures are moderate and soil moisture levels are adequate. A single soil sample $(20 \mathrm{~cm} \times 20 \mathrm{~cm} \times 20 \mathrm{~cm})$ was taken in the centre of each plot and the earthworms were collected by careful hand sorting. After washing and air drying, the total weight of the earthworms from each plot was recorded.

\subsection{Dry matter (DM) yield of maize}

On September 16, 2003, the central $6 \mathrm{~m}^{2}$ of each plot was harvested. Ears and vegetative parts were collected

Table 1

Applied quantities of compost and slurry in the period 1997-2003

\begin{tabular}{|c|c|c|c|c|c|c|c|}
\hline \multirow[t]{2}{*}{ Year } & \multicolumn{3}{|c|}{ Slurry (ton ha ${ }^{-1}$ ) } & \multicolumn{4}{|c|}{ VFG compost (ton $\mathrm{ha}^{-1}$ ) } \\
\hline & $\mathrm{S}+$ & $\mathrm{S}-$ & Application date & $\mathrm{C} 0$ & $\mathrm{C} 1$ & $\mathrm{C} 2$ & Application date \\
\hline 1997 & 53.1 & 0.0 & $04 / 15$ & 0.0 & 22.5 & 45.0 & $04 / 22$ \\
\hline 1998 & 43.1 & 0.0 & $05 / 05$ & 0.0 & 22.5 & 0.0 & $05 / 12$ \\
\hline 1999 & 39.4 & 0.0 & $05 / 05$ & 0.0 & 22.5 & 45.0 & $05 / 7,10,11$ \\
\hline 2000 & 37.0 & 0.0 & $05 / 03$ & 0.0 & 22.5 & 0.0 & $05 / 08$ \\
\hline 2001 & 38.8 & 0.0 & $05 / 15$ & 0.0 & 22.5 & 45.0 & $05 / 21$ \\
\hline 2002 & 53.8 & 0.0 & $05 / 03$ & 0.0 & 22.5 & 0.0 & $05 / 15$ \\
\hline 2003 & 43.1 & 0.0 & $03 / 28$ & 0.0 & 22.5 & 45.0 & $04 / 22$ \\
\hline
\end{tabular}


Table 2

Average composition (standard deviation between brackets) of the applied cattle slurry and VFG compost (1997-2003)

\begin{tabular}{|c|c|c|}
\hline & Slurry & VFG compost \\
\hline $\mathrm{DM}(\%)$ & $6.9(1.0)$ & $71.9(3.9)$ \\
\hline C/N-ratio & $8.1(0.6)$ & $10.9(1.1)$ \\
\hline $\begin{array}{l}\mathrm{N}\left(\mathrm{g}^{-1} \text { or } \mathrm{g} \mathrm{kg}^{-1} \text { of }\right. \\
\text { fresh matter) }\end{array}$ & $3.7(0.9)$ & $14.1(1.3)$ \\
\hline $\mathrm{NO}_{3}^{-}-\mathrm{N}(\mathrm{mg} / \mathrm{l})$ & $25.5(14.7)$ & $118.3(38.9)$ \\
\hline $\mathrm{NH}_{4}^{+}-\mathrm{N}(\mathrm{mg} / \mathrm{l})$ & $2296.5(327.0)$ & $224.4(29.7)$ \\
\hline $\mathrm{P}\left(\mathrm{g} \mathrm{kg}^{-1}\right.$ of fresh matter $)$ & $0.6(0.1)$ & $3.3(0.3)$ \\
\hline $\mathrm{K}\left(\mathrm{g} \mathrm{kg}^{-1}\right.$ of fresh matter $)$ & $3.7(0.9)$ & $11.3(1.6)$ \\
\hline $\mathrm{OM}\left(\mathrm{g} \mathrm{kg}^{-1}\right.$ of fresh matter $)$ & $50.8(7.9)$ & $282.1(23.0)$ \\
\hline
\end{tabular}

and weighted separately. Vegetative parts were chopped and dried for $12 \mathrm{~h}$ at $75^{\circ} \mathrm{C}$. Ears were dried unchopped for $12 \mathrm{~h}$ at $80{ }^{\circ} \mathrm{C}$ and for $4 \mathrm{~h}$ at $105^{\circ} \mathrm{C}$.

\subsection{Statistical analysis}

The data were analysed (ANOVA) using S-Plus software. Since the interaction between the factors slurry and compost was in none of the cases significant, the analysis considered only individual effects.

\section{Results}

\subsection{Nematodes}

Seven years of different organic fertilizer treatments influenced nematode presence. The diversity of plant parasitic nematodes was restricted to only one species of the genus Pratylenchus and a restricted number of species of the family Tylenchidae. At both samplings the plant parasitic nematodes were less abundant in plots receiving organic amendments (Table 3 ). However the type of organic matter determined the presence of the species: Pratylenchus was more abundant when no compost was applied ( $\mathrm{C} 0$ vs. $\mathrm{C} 1$ and $\mathrm{C} 2$ ), while the species belonging to the Tylenchidae were in higher number in plots without cattle slurry application ( $\mathrm{S}+\mathrm{vs}$. S-). In autumn 2003, the difference in abundance between plots with or without the organic amendments mentioned above, was significant $(p<0.05)$ for both nematode groups, while in spring 2004 only the effect of the applied slurry on the presence of the Tylenchidae was significant $(p<0.05)$.

During autumn 2003 the population of the bacteriophagous Rhabditidae was larger on plots with organic amendments. Differences were not significant $(p<0.05)$.

\subsection{Springtails and mites}

For both springtails and mites the trend was very similar: adding organic amendments resulted in increased numbers of these micro-arthropods, both in autumn 2003 and in spring 2004 (Table 4). The lowest number of micro-arthropods was in all cases found on plots which received no compost (C0). For the Collembola the highest number was found on the $\mathrm{C} 2$ plots and this difference was significant $(p<0.05)$ for both sampling periods. Almost all springtails identified in the samples belonged to the Onychiuridae; a few were representatives of the Sminthuridae. The Acari were more abundant on the $\mathrm{C} 1$ plots than on the $\mathrm{C} 2$ plots, but this difference was not significant $(p<0.05)$ for neither of the sampling periods. Some of the most abundant mites in the samples were identified to family level, as being representatives of the Tarsonemidae (Prostigmata), and of the Phytoseiidae and the Laelapidae (Mesostigmata). There was no significant effect of the slurry on the abundance of the micro-arthropods.

\subsection{Earthworms}

The large difference between the two sampling dates is striking (Table 5). Owing to the very dry summer (Table 6), almost no earthworms were found in autumn 2003.

Most individuals and the highest biomass were found on the $\mathrm{C} 1$ plots. The difference with the other treatments was significant $(p<0.05)$ in spring 2004 , but not in 2003. Earthworms were less frequent on the C0 plots. As for the micro-arthropods, the slurry had no significant effect on the abundance of the earthworms.

\subsection{Maize DM yield}

Figs. 2 and 3 illustrate the evolution of the maize DM yield (ears and total DM production) from 1997 till 2003.

Similar fluctuations can be seen on both graphs: $\mathrm{S}-\mathrm{C} 0$ had the lowest DM yield and the treatments $\mathrm{S}+\mathrm{C} 1$ and $\mathrm{S}+\mathrm{C} 2$ had the highest yield. The low DM yield in 1998 was possibly due to an excessive precipitation during early spring and in June, followed by very dry conditions in July and abundant precipitation from the end of August (data not shown) [29]. Table 7 gives the DM yield of the year 2003. The application of compost and slurry had a significant $(p<0.05)$ influence on both the ear and total DM yield. 
Table 3

Average number of nematodes in $100 \mathrm{ml}$ soil, sampled on $03 / 09 / 11$ and $04 / 03 / 30(\mathrm{~S}-=$ no slurry, $\mathrm{S}+=$ slurry, C0= no compost, $\mathrm{C} 1=22.5$ ton $\mathrm{ha}^{-1}$ compost yearly, $\mathrm{C} 2=45$ ton $\mathrm{ha}^{-1}$ compost every other year)

\begin{tabular}{|c|c|c|c|c|c|c|c|}
\hline & & Pratylenchus sp. & Relative & Tylenchidae & Relative & Rhabditidae & Relative \\
\hline \multicolumn{8}{|c|}{ 03/09/11 } \\
\hline & $\mathrm{CO}$ & $667 \mathrm{a}^{\mathrm{a}}$ & 100 & $630 \mathrm{c}$ & 100 & $478 \mathrm{e}$ & 100 \\
\hline \multirow[t]{2}{*}{$\mathrm{S}-$} & $\mathrm{C} 1$ & $623 \mathrm{~b}$ & 94 & $473 \mathrm{c}$ & 75 & $713 \mathrm{e}$ & 149 \\
\hline & $\mathrm{C} 2$ & $317 \mathrm{~b}$ & 48 & $440 \mathrm{c}$ & 70 & $520 \mathrm{e}$ & 109 \\
\hline \multirow[t]{2}{*}{ Aver. } & & 536 & 100 & 514 & 100 & 570 & 100 \\
\hline & $\mathrm{C} 0$ & $1200 \mathrm{a}$ & 100 & $290 \mathrm{~d}$ & 100 & $493 \mathrm{e}$ & 100 \\
\hline \multirow[t]{2}{*}{$\mathrm{S}+$} & $\mathrm{C} 1$ & $423 \mathrm{~b}$ & 35 & $210 \mathrm{~d}$ & 72 & $693 \mathrm{e}$ & 141 \\
\hline & $\mathrm{C} 2$ & $587 \mathrm{~b}$ & 49 & $133 \mathrm{~d}$ & 46 & $617 \mathrm{e}$ & 125 \\
\hline Aver. & & 737 & 138 & 211 & 41 & 601 & 105 \\
\hline \multicolumn{8}{|c|}{ 04/03/30 } \\
\hline & $\mathrm{CO}$ & $667 \mathrm{a}$ & 100 & $593 \mathrm{~b}$ & 100 & $400 \mathrm{~d}$ & 100 \\
\hline \multirow[t]{2}{*}{$S-$} & $\mathrm{C} 1$ & $143 \mathrm{a}$ & 21 & $187 \mathrm{~b}$ & 32 & $137 \mathrm{~d}$ & 34 \\
\hline & $\mathrm{C} 2$ & $163 \mathrm{a}$ & 24 & $277 \mathrm{~b}$ & 47 & $153 \mathrm{~d}$ & 38 \\
\hline \multirow[t]{2}{*}{ Aver. } & & 324 & 100 & 352 & 100 & 230 & 100 \\
\hline & $\mathrm{CO}$ & $180 \mathrm{a}$ & 100 & $130 \mathrm{c}$ & 100 & $247 \mathrm{~d}$ & 100 \\
\hline \multirow[t]{2}{*}{$\mathrm{S}+$} & $\mathrm{C} 1$ & $177 \mathrm{a}$ & 98 & $87 \mathrm{c}$ & 67 & $180 \mathrm{~d}$ & 73 \\
\hline & $\mathrm{C} 2$ & $180 \mathrm{a}$ & 100 & $103 \mathrm{c}$ & 79 & $253 \mathrm{~d}$ & 102 \\
\hline Aver. & & 179 & 55 & 107 & 30 & 227 & 99 \\
\hline
\end{tabular}

${ }^{\text {a }}$ Different letters indicate a significant difference between the treatments per sampling date according to Tukey $(p<0.05)$.

\section{Discussion}

The effects of organic amendments on the population dynamics of plant parasitic nematodes such as Pratylenchus sp. and the Tylenchidae have been investigated before, but the results are not at all univocal. McSorley et al. [27] and Bulluck et al. [8] found that plant parasitic nematode communities were not affected by organic soil amendments, and argue that this is consistent with other (short term) research. In contrast, Weiss et al. [38] described an increase in the number of plant parasitic nematodes after long term application of sewage sludge. The most important reason for this increase was probably an enhanced nutrient availability, which resulted in a higher plant biomass, and hence a higher root biomass. Particularly the genus Pratylenchus seemed to benefit from the addition of sewage sludge. Forge et al. [22] also concluded that the sustained use of dairy manure increased population densities of Pratylenchus penetrans. In contrast Akhtar [1] observed a decrease in the number of plant parasitic nematodes with increasing amounts of compost (cattle solid manure and leaves) applied. These contradicting results may be linked to the quality of the organic matter applied (sewage sludge as opposed to compost). Indeed, Bongers [6] stated that the effect of organic amendments on plant parasitic nematodes depends on the specific type of organic matter, the $\mathrm{C} / \mathrm{N}$-ratio, the

Table 4

Average number of springtails (Collembola) and mites (Acari), sampled on 03/11/14 and 04/03/19 (S - = no slurry, $\mathrm{S}+=$ slurry, C0 $=$ no compost, $\mathrm{C} 1=22.5$ ton $\mathrm{ha}^{-1}$ compost yearly, $\mathrm{C} 2=45$ ton $^{-1} \mathrm{a}^{-1}$ compost every other year)

\begin{tabular}{|c|c|c|c|c|c|c|}
\hline & \multicolumn{2}{|l|}{$\mathrm{CO}$} & \multicolumn{2}{|l|}{$\mathrm{C} 1$} & \multicolumn{2}{|l|}{$\mathrm{C} 2$} \\
\hline & Collembola & Acari & Collembola & Acari & Collembola & Acari \\
\hline \multicolumn{7}{|l|}{$03 / 11 / 14$} \\
\hline Aver. $\mathrm{S}_{-}$ & $3.3 \mathrm{a}^{\mathrm{a}}$ & $22.0 \mathrm{c}$ & $11.0 \mathrm{ab}$ & $31.0 \mathrm{c}$ & $21.7 \mathrm{~b}$ & $25.0 \mathrm{c}$ \\
\hline Aver. S+ & $6.3 \mathrm{a}$ & $6.0 \mathrm{c}$ & $10.3 \mathrm{ab}$ & $47.7 \mathrm{c}$ & $31.3 \mathrm{~b}$ & $13.0 \mathrm{c}$ \\
\hline General average & 4.8 & 14.0 & 10.7 & 39.3 & 21.5 & 19.0 \\
\hline Relative & 100 & 100 & 223 & 281 & 448 & 136 \\
\hline \multicolumn{7}{|l|}{$04 / 03 / 19$} \\
\hline Aver. S- & $3.3 \mathrm{a}^{\mathrm{a}}$ & $10.7 \mathrm{c}$ & $8.0 \mathrm{a}$ & $11.7 \mathrm{c}$ & $15.3 \mathrm{~b}$ & $6.0 \mathrm{c}$ \\
\hline Aver. $\mathrm{S}+$ & $4.0 \mathrm{a}$ & $3.3 \mathrm{c}$ & $6.3 \mathrm{a}$ & $4.7 \mathrm{c}$ & $24.7 \mathrm{~b}$ & $8.0 \mathrm{c}$ \\
\hline General average. & 3.7 & 7.0 & 7.2 & 8.2 & 20.0 & 7.0 \\
\hline Relative & 100 & 100 & 195 & 117 & 541 & 100 \\
\hline
\end{tabular}

\footnotetext{
${ }^{a}$ Different letters indicate a significant difference between the treatments per sampling date according to Tukey $(p<0.05)$.
} 
Table 5

Average number and biomass of earthworms, sampled $\left(0.2 \times 0.2 \times 0.2 \mathrm{~m}^{3}\right)$ on $03 / 10 / 20$ and $04 / 03 / 16(\mathrm{~S}-=$ no slurry, $\mathrm{S}+=$ slurry, $\mathrm{C} 0=$ no compost, $\mathrm{C} 1=22.5$ ton $\mathrm{ha}^{-1}$ compost yearly, $\mathrm{C} 2=45$ ton $^{-1} \mathrm{a}^{-1}$ compost every other year)

\begin{tabular}{|c|c|c|c|c|c|c|}
\hline & \multicolumn{2}{|l|}{$\mathrm{C} 0$} & \multicolumn{2}{|l|}{$\mathrm{C} 1$} & \multicolumn{2}{|l|}{$\mathrm{C} 2$} \\
\hline & Number & Mass (g) & Number & Mass (g) & Number & Mass (g) \\
\hline \multicolumn{7}{|l|}{ 03/10/20 } \\
\hline Aver. S- & $0.67 \mathrm{a}^{\mathrm{a}}$ & $0.17 \mathrm{~b}$ & $1.67 \mathrm{a}$ & $0.67 \mathrm{~b}$ & $1.00 \mathrm{a}$ & $0.25 \mathrm{~b}$ \\
\hline Aver. S+ & $0.67 \mathrm{a}$ & $0.15 \mathrm{~b}$ & $0.33 \mathrm{a}$ & $0.02 \mathrm{~b}$ & $0.67 \mathrm{a}$ & $0.36 \mathrm{~b}$ \\
\hline General aver. & 0.67 & 0.16 & 1.00 & 0.34 & 0.84 & 0.30 \\
\hline Relative & 100 & 100 & 149 & 213 & 125 & 188 \\
\hline \multicolumn{7}{|l|}{$04 / 03 / 16$} \\
\hline Aver. S- & $0.67 \mathrm{a}^{\mathrm{a}}$ & $0.03 \mathrm{c}$ & $6.67 \mathrm{~b}$ & $1.23 \mathrm{~d}$ & $2.00 \mathrm{ab}$ & $0.51 \mathrm{c}$ \\
\hline Aver. S+ & $1.33 \mathrm{a}$ & $0.27 \mathrm{c}$ & $3.00 \mathrm{~b}$ & $0.90 \mathrm{~d}$ & $2.33 \mathrm{ab}$ & $0.44 \mathrm{c}$ \\
\hline General aver. & 1.00 & 0.15 & 4.83 & 1.07 & 2.17 & 0.47 \\
\hline Relative & 100 & 100 & 483 & 713 & 217 & 313 \\
\hline
\end{tabular}

${ }^{\mathrm{a}}$ Different letters indicate a significant difference between the treatments per sampling date according to Tukey $(p<0.05)$.

contaminants present, which and how many nematodes and possible antagonists are present in the organic fertilizer and the length of the application period of the organic amendments. More consistent effects on nematode abundance are observed where organic amendments have been applied for several years [27].

In our study, there was a clear tendency towards less plant parasitic nematodes on plots with organic amendments, despite the different reactions of Pratylenchus sp. and the Tylenchidae on the compost and the slurry application.

For the Rhabditidae no significant differences were found, although they tended to be more abundant on plots with organic amendments. Nevertheless, the increase of Rhabditidae in enriched situations has also been observed in other studies $[1,5,8,38]$. Increased populations of bacterivorous nematodes, e.g. Rhabditidae, can be linked directly to higher populations of bacteria that are associated with the input of organic amendments like compost and slurry. Ettema and Bongers [17] found that the explosive growth of the rhabditid population, caused by the very high nutrient density, took place immediately after manuring and peaked after two or three weeks. Because of early reproduction, these colonizers escaped competition with other nematode groups. Two weeks after this peak population had been reached, the numbers of these nematodes started to decrease again and about twenty weeks after manuring the population was reduced to less then one quarter of the peak population. Increased competition or parasitism might cause this decline in rhabditid numbers, but little is known of such interactions [17].

The greatest numbers of soil micro-arthropods were found on plots amended with compost. Being considered fungal, and more general microbial, feeders $[20,26]$, the results for the Collembola are not surprising and corroborate previous research [28,33]. It is conceivable that microbial growth derived from the organic material added to the soil increased the food availability for the springtails [31], allowing the population to grow. Both in autumn 2003 and spring 2004 the Collembola were most abundant on plots treated every other year with 45 ton compost ha ${ }^{-1}$ (C2), and since the two yearly amendment was applied in 2003 a high mass of OM was added.

On the contrary, the highest numbers of mites were found on the C1-plots. Because mites were only identified to family level, interpretation of the data is more difficult then for the Collembola. Some of the mites present in the soil samples belonged to the Tarsonemidae (Prostigmata). Most of the Tarsonemidae mites

Table 6

Precipitation $(\mathrm{mm})$ and average monthly air temperature $\left({ }^{\circ} \mathrm{C}\right)$ during summer and autumn 2003 compared to the long-term average ("Norm") at Melle

\begin{tabular}{|c|c|c|c|c|c|c|}
\hline & June & July & August & September & October & November \\
\hline Precipitation & 45.6 & 57.0 & 54.0 & 25.9 & 47.7 & 47.9 \\
\hline Norm & 65.0 & 72.0 & 74.0 & 72.0 & 72.0 & 64.0 \\
\hline Average air temperature & 18.2 & 18.8 & 19.5 & 14.9 & 8.0 & 7.8 \\
\hline Norm & 15.1 & 16.8 & 16.7 & 14.4 & 10.3 & 6.2 \\
\hline
\end{tabular}




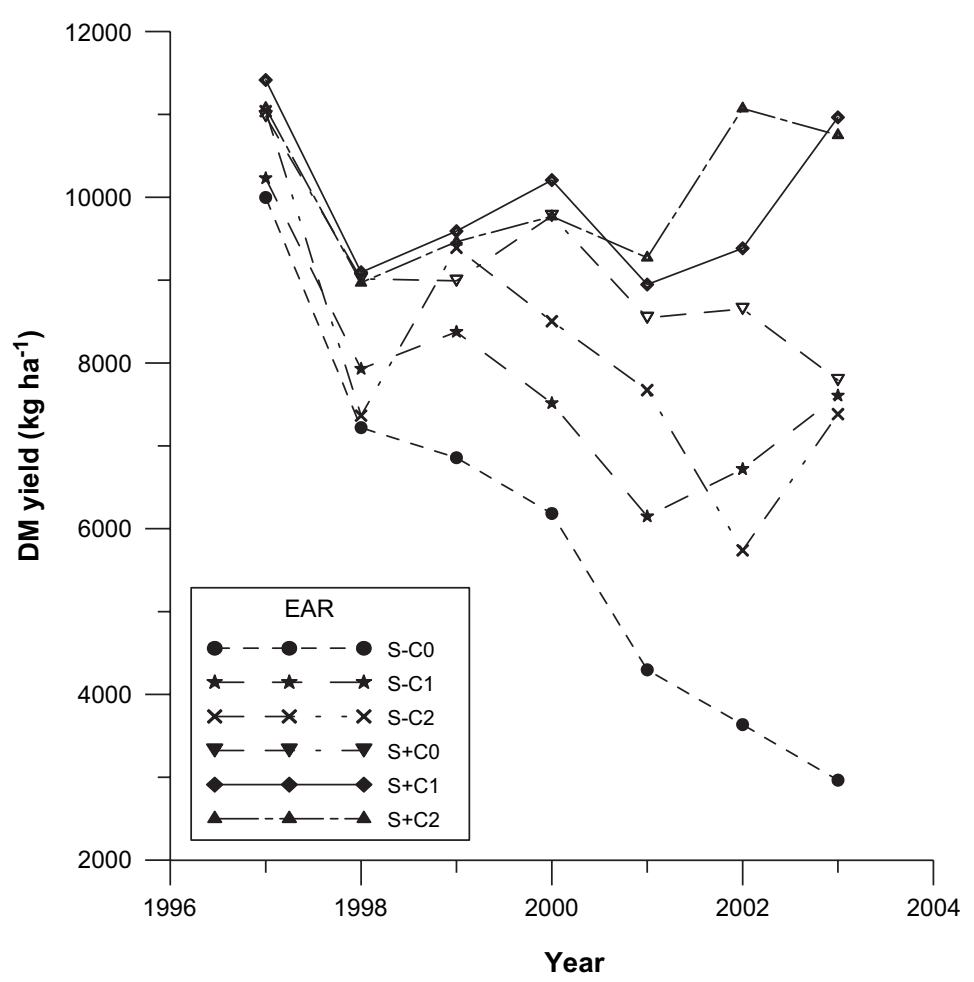

Fig. 2. Evolution of the average ear DM yield (kg/ha) between 1997 and 2003 ( $\mathrm{S}-=$ no slurry, $\mathrm{S}+=\mathrm{slurry}$, C0 = no compost, $\mathrm{C} 1=22.5$ ton $\mathrm{ha}^{-1}$ compost yearly, $\mathrm{C} 2=45$ ton ha $^{-1}$ compost every other year).

are characterized by their fungivorous or phytophagous dietary habits [18]. In order to come to more conclusive results about the effect of compost and/or slurry application on populations of soil mites, identification up to species level would be necessary.

Addition of organic matter is believed to be one of the major management variables affecting earthworm populations. Organic amendments increase earthworm populations by providing food sources and increasing the overall levels of soil organic matter [4]. Different studies have shown that earthworms prefer soils with a high organic matter content [14]. Our findings are in agreement with those studies. In spring 2004 significantly more earthworms with a higher total biomass were found on plots amended with VFG compost, while no effect of the application of slurry could be seen. It is striking that the number and biomass of the earthworms on $\mathrm{C} 1$ plots were much higher than on the $\mathrm{C} 2$ plots, although the latter plots received 45 ton ha ${ }^{-1}$ compost in 2003. Similar results were found in 2001 [10]. Apparently, yearly doses of compost stimulate earthworms more than larger applications every other year.

The hot and dry summer of 2003 (Table 6) greatly reduced the active earthworm population during autumn 2003. Temperature and moisture are the two major environmental variables affecting earthworm populations $[4,14]$. Other studies confirmed that a period of severe drought has a significant negative influence on the active earthworm population [4,34].

The ear and total DM yield was the highest when VFG compost was applied together with slurry, due to the higher amount of total plant available (i.e. mineral) $\mathrm{N}$ applied. Applying the compost yearly $(\mathrm{S}+\mathrm{C} 1)$ or every other year $(\mathrm{S}+\mathrm{C} 2)$, did not result in significant differences.

The use of only compost had a significant impact on the DM yield, with the discrepancy getting larger each year $(\mathrm{S}-\mathrm{C} 0$ versus $\mathrm{S}-\mathrm{C} 1$ and $\mathrm{S}-\mathrm{C} 2$ ). The first years of the experiment there was a clear downward trend in DM yield on plots without slurry application $(\mathrm{S}-)$, but in the last two years this trend was reverted on plots receiving compost $(\mathrm{S}-\mathrm{C} 1$ and $\mathrm{S}-\mathrm{C} 2)$. In the last year the application of only VFG compost (yearly or every other year) and the application of only slurry $(\mathrm{S}-\mathrm{C} 1$ and $\mathrm{S}-\mathrm{C} 2$ versus $\mathrm{S}+\mathrm{C} 0$ ) even resulted in comparable DM yields.

A likely explanation is that $\mathrm{N}$ mineralization from VFG compost, a stable organic matter, is very limited in the short term, but that there is a significant residual 


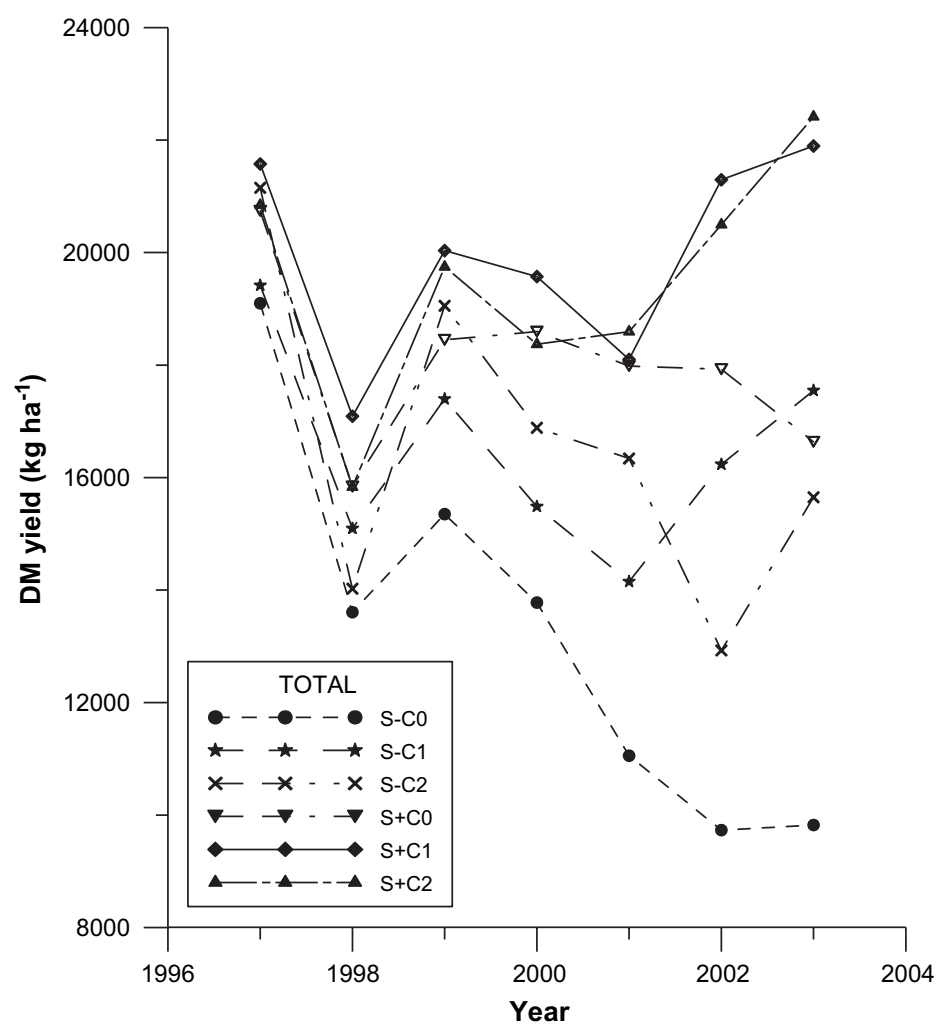

Fig. 3. Evolution of the average total DM yield (kg/ha) between 1997 and 2003 ( $\mathrm{S}-=$ no slurry, S+= slurry, C0 = no compost, $\mathrm{C} 1=22.5$ ton $\mathrm{ha}^{-1}$ compost yearly, $\mathrm{C} 2=45$ ton $^{-1}$ compost every other year).

$\mathrm{N}$ effect from the cumulative applications which becomes visible after $4-5$ years, resulting in higher $\mathrm{N}$ availability and yields. Although the $\mathrm{N}$ availability from compost is small in the short term, it becomes very large after many years of compost application. Moreover repeated compost application stimulates the soil food web, thus enhancing $\mathrm{N}$ turnover in the

Table 7

Influence of the application of slurry and compost on the average maize dry matter yield of 2003 (ear and total), harvested on 03/09/16 $\left(\mathrm{S}-=\right.$ no slurry, $\mathrm{S}+=$ slurry, $\mathrm{C} 0=$ no compost, $\mathrm{C} 1=22.5$ ton $\mathrm{ha}^{-1}$ compost yearly, $\mathrm{C} 2=45$ ton $\mathrm{ha}^{-1}$ compost every other year)

\begin{tabular}{llll}
\hline & & Ear DM yield $(\mathrm{kg} / \mathrm{ha})$ & Total DM yield $(\mathrm{kg} / \mathrm{ha})$ \\
\hline & $\mathrm{C} 0$ & $2965 \mathrm{a}^{\mathrm{a}}$ & $9823 \mathrm{e}$ \\
$\mathrm{S}-$ & $\mathrm{C} 1$ & $7606 \mathrm{~b}$ & $17548 \mathrm{f}$ \\
& $\mathrm{C} 2$ & $7384 \mathrm{~b}$ & $15652 \mathrm{f}$ \\
Aver. & & 5985 & 14341 \\
& $\mathrm{C} 0$ & $7794 \mathrm{c}$ & $16636 \mathrm{~g}$ \\
$\mathrm{~S}+$ & $\mathrm{C} 1$ & $10965 \mathrm{~d}$ & $21895 \mathrm{~h}$ \\
& $\mathrm{C} 2$ & $10750 \mathrm{~d}$ & $22416 \mathrm{~h}$ \\
Aver. & & 9836 & 20315 \\
\hline
\end{tabular}

${ }^{\text {a }}$ Different letters indicate a significant difference between the treatments according to Tukey $(p<0.05)$. long term. Weinzaepflen et al. [37] found higher $\mathrm{N}$ mineralization rates, and so higher amounts of available $\mathrm{N}$, after the second year of compost application compared to the first. This might be explained too by the cumulative effect of the compost. Another explanation for the positive long term effect of repeated compost application on yield is the effect on the soil physical properties, improving the physical growing conditions (water uptake, aeration, ...) for the crop, and this effect will be more pronounced in extreme years such as 2003. Nevens and Reheul [29] also suggest that the positive yield effect of the compost was not a mere $\mathrm{N}$ effect.

In conclusion the VFG compost application had a positive effect both on maize DM yield and on the investigated soil fauna, with generally higher numbers of beneficial organisms and less parasitic nematodes on plots amended with compost. The effect of slurry was less explicit.

Very little information is available on how these changes in soil fauna composition affect crop performance and soil quality. Therefore more research is urgently needed to quantify the agronomic and environmental significance of such changes in soil fauna and 
flora composition in order to allow for an effective management of the soil food web.

\section{Acknowledgements}

The authors wish to thank Nancy De Sutter and Johan Witters from the Institute for Agricultural and Fisheries Research, for assistance with the identification of the nematodes, springtails and mites, and Franky Van Peteghem and Jean-Pierre Van Maerke for their assistance with the field work.

\section{References}

[1] M. Akhtar, Plant growth and nematode dynamics in response to soil amendments with neem products, urea and compost, Bioresour. Technol. 69 (1999) 181-183.

[2] Anonymous, Activiteitenverslag 2004 Vlaco, Vlaco, Mechelen, 2005 Vlaco Activity Report 2004 (in Dutch).

[3] P. Bazzoffi, S. Pellegrini, A. Rocchini, M. Morandi, O. Grasselli, The effect of urban refuse compost and different tractors tyres on soil physical properties, soil erosion and maize yield, Soil Tillage Res. 48 (1998) 275-286.

[4] P.J. Bohlen, W.M. Edwards, C.A. Edwards, Earthworm community structure and diversity in experimental agricultural watersheds in Northeastern Ohio, Plant Soil 170 (1995) 233-239.

[5] T. Bongers, The maturity index: an ecological measure of environmental disturbance based on nematode species composition, Oecologia 83 (1991) 14-19.

[6] T. Bongers, Personal communication, 2004.

[7] L. Brussaard, T.W. Kuyper, W.A.M. Didden, R.G.M. de Goede, J. Bloem, Biological soil quality from biomass to biodiversity importance and resilience to management stress and disturbance, in: P. Schjonning, S. Elmholt, B.T. Christensen (Eds.), Managing Soil Quality: Challenges in Modern Agriculture, CAB International, Wallingford, 2004, pp. 139-161.

[8] L.R. Bulluck, K.R. Barker, J.B. Ristaino, Influences of organic and synthetic soil fertility amendments on nematode trophic groups and community dynamics under tomatoes, Appl. Soil Ecol. 21 (2002) 233-250.

[9] I. Celik, I. Ortas, S. Kilic, Effects of compost, mycorrhiza, manure and fertilizer on some physical properties of a Chromoxerert soil, Soil Tillage Res. 78 (2004) 59-67.

[10] V. Christiaens, F. Nevens, D. Reheul, The effect of vegetable, fruit and garden waste compost on the biomass production and number of earthworms in a silage maize monoculture. Lecture: Applying Compost - Benefits and Needs, Brussels, 22-23 November 2001.

[11] M.A. De Brito Alvarez, S. Gagne, H. Antoun, Effect of compost on rhizosphere microflora of the tomato and on the incidence of plant growth-promoting rhizobacteria, Appl. Environ. Microbiol. 61 (1995) 194-199.

[12] W.A.M. Didden, Personal communication on sampling of soil fauna, 2003.

[13] W. Dunger, H.J. Fiedler, Methoden der Bodenbiologie, Gustav Fisher, Jena, 1997.

[14] C.A. Edwards, P.J. Bohlen, Biology and Ecology of Earthworms, Chapman \& Hall, London, 1996.
[15] L. Edwards, J.R. Burney, G. Richter, A.H. MacRae, Evaluation of compost and straw mulching on soil-loss characteristics in erosion plots of potatoes in Prince Edward Island, Canada, Agric. Ecosyst. Environ. 81 (2000) 217-222.

[16] E. Epstein, The Science of Composting, Technomic Publishing Company, Lancaster, 1997.

[17] C.H. Ettema, T. Bongers, Characterization of nematode colonization and succession in disturbed soil using the Maturity Index, Biol. Fertil. Soils 16 (1993) 79-85.

[18] G.O. Evans, Principles of Acarology, CAB International, Wallingford, 1992.

[19] L.B. Faucette, L.M. Risse, M.A. Nearing, J.W. Gaskin, L.T. West, Runoff, erosion and nutrient losses from compost and mulch blankets under simulated rainfall, J. Soil Water Cons. 59 (2004) 154-160.

[20] J. Filser, The role of Collembola in carbon and nitrogen cycling in soil, Pedobiologia 46 (2002) 234-245.

[21] T.A. Forge, E. Hogue, G. Neilsen, D. Neilsen, Effects of organic mulches on soil microflora in the root zone of apple: implications for nutrient fluxes and functional diversity of the soil food web, Appl. Soil Ecol. 22 (2003) 39-54.

[22] T.A. Forge, S. Bittman, C.G. Kowalenko, Impacts of sustained use of dairy manure slurry and fertilizers on populations of Pratylenchus penetrans under tall fescue, J. Nematol. 37 (2005) 207-213.

[23] G. Hendrickx, An automatic apparatus for extracting free-living nematode stages from soil, Nematologica 41 (1995) 308 (abstr.).

[24] H.A.J. Hoitink, M.J. Boehm, Y. Hadar, Mechanisms of suppression of soil borne plant pathogens in compost, in: H.A.J. Hoitink, H. Keener (Eds.), Science and Engineering of Composting: Design, Environmental, Microbiological, and Utilization Aspects, Renaissance Publications, Worthington, 1993, pp. 602-621.

[25] H.A.J. Hoitink, M.S. Krause, D.Y. Hahn, Spectrum and mechanisms of plant disease control with composts, in: P.J. Stofella, B.A. Kahn (Eds.), Compost Utilization in Horticultural Cropping Systems, Lewis Publishers, New York, 2001, pp. 263274.

[26] H.W. Hunt, D.C. Coleman, E.R. Ingham, R.E. Ingham, E.T. Elliot, J.C. Moore, S.L. Rose, C.P.P. Reid, C.R. Morley, The detrital food web in a shortgrass prairie, Biol. Fertil. Soils 3 (1987) 57-68.

[27] R. McSorley, R.N. Gallaher, Effect of compost and maize cultivars on plant-parasitic nematodes, Suppl. J. Nematol. 29 (1997) 731-736.

[28] K. Miyazawa, H. Tsuji, M. Yamagata, H. Nakano, T. Nakamoto, The effects of cropping systems and fallow managements on microarthropod populations, Plant Prod. Sci. 5 (2002) 257-265.

[29] F. Nevens, D. Reheul, The application of vegetable, fruit and garden waste (VFG) compost in addition to cattle slurry in a silage monoculture: nitrogen availability and use, Eur. J. Agron. 19 (2003) 189-203.

[30] M. Ozores-Hampton, T.A. Obreza, P.J. Stoffella, Weed control in vegetable crops with composted organic mulches, in: P.J. Stofella, B.A. Kahn (Eds.), Compost Utilization in Horticultural Cropping Systems, Lewis Publishers, New York, 2001, pp. 275-286.

[31] S.O. Petersen, K. Henrikson, G.K. Mortensen, P.H. Krogh, K.K. Brandt, J. Sorensen, T. Madsen, J. Petersen, C. Gron, Recycling of sewage sludge and household compost to arable 
land: fate and effects of organic contaminants, and impact on soil fertility, Soil Tillage Res. 72 (2003) 139-152.

[32] G.H. Pfotzer, C. Schüler, Effects of different compost amendments on soil biotic and faunal feeding activity in an organic farming system, Biol. Agric. Hortic. 15 (1997) 177-183.

[33] K. Scholte, M. Lootsma, Effects of farmyard manure and green manure crops on populations of mycophagous soil fauna and Rhizoctania stem canker of potato, Pedobiologia 42 (1998) 223-231.

[34] M.L. Schindler Wessells, P.J. Bohlen, D.A. McCartney, S. Subler, C.A. Edwards, Earthworm effects on soil respiration in corn agroecosystems receiving different nutrient inputs, Soil Biol. Biochem. 29 (1997) 409-412.

[35] M.L. Stratton, J.E. Rechcigl, Organic mulches, wood products, and composts as soil amendments and conditioners, in: A. Wallace,
R.E. Terry (Eds.), Handbook of Soil Conditioners Substances that Enhance the Physical Properties of Soil, Marcel Dekker, New York, 1998, pp. 43-95.

[36] C.H. Van den Berghe, N.V. Hue, Liming potential of composts applied to an acid oxisol in Burundi, Compost Sci. Util. 7 (1999) 40-46.

[37] E. Weinzaepflen, B. Tychon, B. Godden, Use of mineralization kinetics to estimate the agricultural value of a compost incorporated into a vineyard in Luxembourg, Proceedings of the International Composting Symposium, Halifax/Dartmouth (Canada), 19-23.09.1999, pp. 876-884.

[38] B. Weiss, O. Larink, Influence of sewage sludge and heavy metals on nematodes in an arable soil, Biol. Fertil. Soils 12 (1991) 5-9. 